\title{
Cleidocranial Dysplasia: Diagnosis, Surgical and Orthodontic Planning and Interventions in a Pediatric Patient
}

\author{
Displasia Cleidocraneal: Diagnóstico, Planificación Quirúrgica \\ y Ortodóncica e Intervenciones en un Paciente Pediátrico
}

\author{
Francine Sumie Morikava*; Rafaela Scariot ${ }^{* *}$ Imara de Almeida Castro Morosini ${ }^{* * *}$; \\ Aline Sebastiani"; Delson João Costa ${ }^{\star * * *}$; Fabian Calixto Fraiz ${ }^{* * * *}$ \& Fernanda Morais Ferreira ${ }^{\star \star * * *}$
}

MORIKAVA, F. S.; SCARIOT, R.; MOROSINI, I. A. C.; SEBASTIANI, A.; COSTA, D. J.; FRAIZ, F. C. \& FERREIRA, F. M. Cleidocranial dysplasia: Diagnosis, surgical and orthodontic planning and interventions in a pediatric patient. Int. $J$. Odontostomat., 10(2):325-331, 2016.

ABSTRACT: Cleidocranial Dysplasia (CCD) is an autosomal dominant bone disorder caused by a defect in the CBFA1 gene and characterized by skeletal, craniofacial and orodental anomalies. This paper describes the main aspects of a case of CCD from diagnosis and planning to the first step of the interventions. An 11-year-old male patient sought the pediatric dentistry clinic of the Federal University of Paraná (Brazil) with the complaint of the prolonged retention of nearly all his primary teeth. Clinical and imaging exams led to the diagnosis of CCD and the treatment plan was outlined. The first step consisted of the extraction of 4 primary, 2 permanent and 2 supernumerary teeth from the maxilla, followed by palate separation, traction of the impacted teeth and reverse traction of the maxilla. The patient remains in treatment. Clinical follow up as well as the awareness and motivation of the family are important factors in such cases.

KEY WORDS: cleidocranial dysplasia, bone diseases, tooth, supernumerary.

\section{INTRODUCTION}

Cleidocranial Dysplasia (CCD), also known as Marie-Sainton Disease and cleidocranial dysostosis (Kalliala \& Taskinen, 1962), is an autosomal dominant bone disorder (Björn \& Grahnén, 1966), but $40 \%$ of cases seem to be spontaneous mutations (Neville et al., 2009). CCD is caused by a defect in the CBFA1 gene, also known as RUNX2, of chromosome 6p21 (Yoshida et al., 2002; Lo Muzio et al., 2007; Purandare et al., 2008), which is essential to the differentiation of osteoblasts as well as bone and tooth formation (Mundlos, 1999; Markovic, 1992). It was once believed that CCD only involved membranous bones, but this condition is currently known to be a generalized disorder of skeletal structures (Rimoin, 1978). The prevalence rate is one per million individuals, with no predilection for race or sex (Regezi et al., 2012). Despite the skeletal, craniofacial and orodental manifestations, the intellectual development of individuals with CCD is normal (Regezi et al.; Cooper et al., 2001). Diagnosis is based on clinical and radiographic findings (Purandare et al.).

Underdevelopment of the clavicle bones is a characteristic of CCD, leading to abnormal mobility of the shoulders, with unilateral or bilateral absence of these bones in approximately $10 \%$ of cases (Neville et al.; Jarvis \& Keats, 1974). The neck exhibits an elongated appearance and the shoulders are narrow and sunken (Neville et al.). Moreover, individuals with this condition tend to be short (Jarvis \& Keats). Other skeletal characteristics include a wide symphysis pubis (Jarvis \& Keats) defects in the bones of the hands and feet, a cone-shaped thorax and lumbar spondylosis (Mundlos; Regezi et al.). Among the craniofacial characteristics, delayed fontanelle closure, open cranial sutures and multiple wormian bones are common

\footnotetext{
MDS Student, DDS, Department of Stomatology, Federal University of Parana, Curitiba, Brazil.

Professor, DDS, MDS, PhD, Positivo University, Curitiba, Brazil.

*** Orthodontist, DDS, MDS, Private practice, Curitiba, Brazil.

Associate Professor, DDS, MDS, PhD, Department of Stomatology, Federal University of Parana, Curitiba, Brazil.

Professor, DDS, MDS, PhD, Department of Pediatric Dentistry and Orthodontics, Federal University of Minas Gerais, Belo Horizonte, Brazil.
} 
findings (Mundlos; Mohan et al.). Other anomalies include a protruding brow ridge, ocular hypertelorism, broad base and depressed dorsum of the nose, underdeveloped middle third of the face, underdeveloped maxilla, malformation of the paranasal sinuses and mandibular protrusion (Mundlos; Winter, 1943).

Individuals with CCD general retain the primary teeth for a prolonged period of time, with the delayed eruption of permanent teeth and the occurrence of supernumerary teeth (Winter). Non-erupted and supernumerary teeth may have dilacerated crowns and roots (Neville et al.). In some cases, the palate is arched and narrow and may even be cleft (Winter).

This paper describes a case of CCD from diagnosis and planning to the surgical and orthodontic interventions, with a discussion of the main clinical and radiographic characteristics.

\section{CASE REPORT}

An 11-year-old white male visited the pediatric dentistry clinic of the Federal University of Paraná (Brazil) for dental treatment. The mother's main complaint was the prolonged retention of nearly all the boy's primary teeth.

The medical history revealed delayed closure of the fontanelles and cranial sutures and a number of health problems since birth, mainly in the respiratory tract. The patient had the mouth-breathing habit and had been taking growth hormone since nine years of age due to his short stature. The extraoral exam revealed that the patient had ocular hypertelorism, broad base and depressed dorsum of the nose (Fig. $1 \mathrm{~A})$, underdeveloped middle third of the face, mild mandibular protrusion, a straight profile compatible with skeletal class III (Fig. 1B) and narrow, sunken shoulders with unusual mobility (Fig. 1C).

The intraoral exam revealed prolonged retention of various primary teeth, the presence of few permanent teeth, anterior and posterior crossbite, class III canine and molar relationships, deviation of the lower midline to the right, atresia of the upper arch (Fig. 2A) and a deep, arched palate. The panoramic radiograph revealed various impacted permanent and supernumerary teeth, some with root dilacerations (Fig. 2B).
Based on the initial exams, the diagnostic hypothesis was CCD. Complementary radiographic exams were solicited for the evaluation of other bone abnormalities. X-rays were taken of the spinal column, lumbosacral spine, ankles, feet and clavicles. The patient exhibited various bone deformities, including hypoplastic vertebral bodies, abnormal bone texture on the posterior face of the left ankle and agenesis of the middle third of each clavicle (Fig. 1D), thereby confirming the diagnosis. The patient exhibited the majority of characteristics of CCD described in the literature (Table I).

The multidisciplinary team analyzed the treatment options. As the patient was still in the growth phase, which increases the odds of success for dental traction and orthopedic correction of the jaws, the decision was made to extract the primary and supernumerary teeth, followed by traction of the impacted permanent teeth and orthopedic correction of the class III malocclusion. This decision was made with the participation of family members, who were informed regarding the extent of the treatment and the lack of predictability in obtaining the eruption of all teeth.

As a highly invasive procedure, the orthodontic and surgical interventions were performed in steps, beginning with the maxilla. The first step of surgical treatment was performed under general anesthesia at the Trabalhador Hospital in the city of Curitiba (Brazil). Extractions were performed of the 4 primary maxillary incisors, 2 supernumerary teeth located in the anterior region and 2 permanent teeth (the permanent maxillary right central incisor and the maxillary right second premolar) (Fig. $3 A-C)$. The decision to extract the permanent teeth was based on the considerable dilacerations and the fact that these teeth were in an unfavorable position for traction. The same region exhibited supernumerary teeth with adequate anatomy and better positioning that could be preserved to substitute these permanent teeth.

Meshes were bonded to the permanent and supernumerary teeth in the maxillary anterior region for traction. The wires were attached to a vestibular arch fixed with previously placed orthodontic bands on the maxillary right and left first molars (Fig. 3D-E). Due to the number of osteotomies performed in the region, the decision was made to await two months before initiating orthodontic traction and the placement of the Haas expander. The onset of the passive eruption of the maxillary lateral incisors was observed one week after surgery. 
Table I. Correspondence among characteristics frequently reported in literature for Cleidocranial Dysplasia and characteristics of patient

\begin{tabular}{|c|c|c|c|}
\hline Characteristic & Yes & No & Not evaluated \\
\hline Unilateral or bilateral absence of clavicle & & $\mathbf{X}$ & \\
\hline Hypoplasia/malformation of clavicle & $\mathbf{x}$ & & \\
\hline Unusual shoulder mobility & $\mathbf{X}$ & & \\
\hline Approximation of shoulders in front of thorax & $\mathbf{X}$ & & \\
\hline Underdevelopment of muscles associated with clavicles & $\mathbf{X}$ & & \\
\hline Neck with elongated appearance; narrow, sunken shoulders & $\mathbf{x}$ & & \\
\hline Short stature & $\mathbf{X}$ & & \\
\hline Wide symphysis pubis & & & $\mathbf{x}$ \\
\hline Defects in bones of hands and feet & $\mathbf{x}$ & & \\
\hline Cone-shaped thorax & & & $\mathbf{x}$ \\
\hline Lumbar spondylosis & $\mathbf{x}$ & & \\
\hline Delayed closure of fontanelles and cranial sutures & $\mathbf{x}$ & & \\
\hline Multiple wormian bones & & & $\mathbf{x}$ \\
\hline Protruded brow ridge & & $\mathbf{X}$ & \\
\hline Ocular hypertelorism & $\mathbf{x}$ & & \\
\hline Broad base and depressed dorsum of nose & $\mathbf{X}$ & & \\
\hline Underdeveloped middle third of face & $\mathbf{x}$ & & \\
\hline Underdeveloped maxilla & $\mathbf{X}$ & & \\
\hline Malformation of paranasal sinuses & & $\mathbf{X}$ & \\
\hline Mandibular protrusion & $\mathbf{x}$ & & \\
\hline Prolonged retention of primary teeth & $\mathbf{X}$ & & \\
\hline Delayed eruption of pemanent teeth & $\mathbf{X}$ & & \\
\hline Presence of supernumerary teeth & $\mathbf{x}$ & & \\
\hline Non-erupted and supernumerary teeth with crown/root dilaceration & $\mathbf{X}$ & & \\
\hline Narrow, arched palate & $\mathbf{x}$ & & \\
\hline Cleft palate & & $\mathbf{x}$ & \\
\hline
\end{tabular}

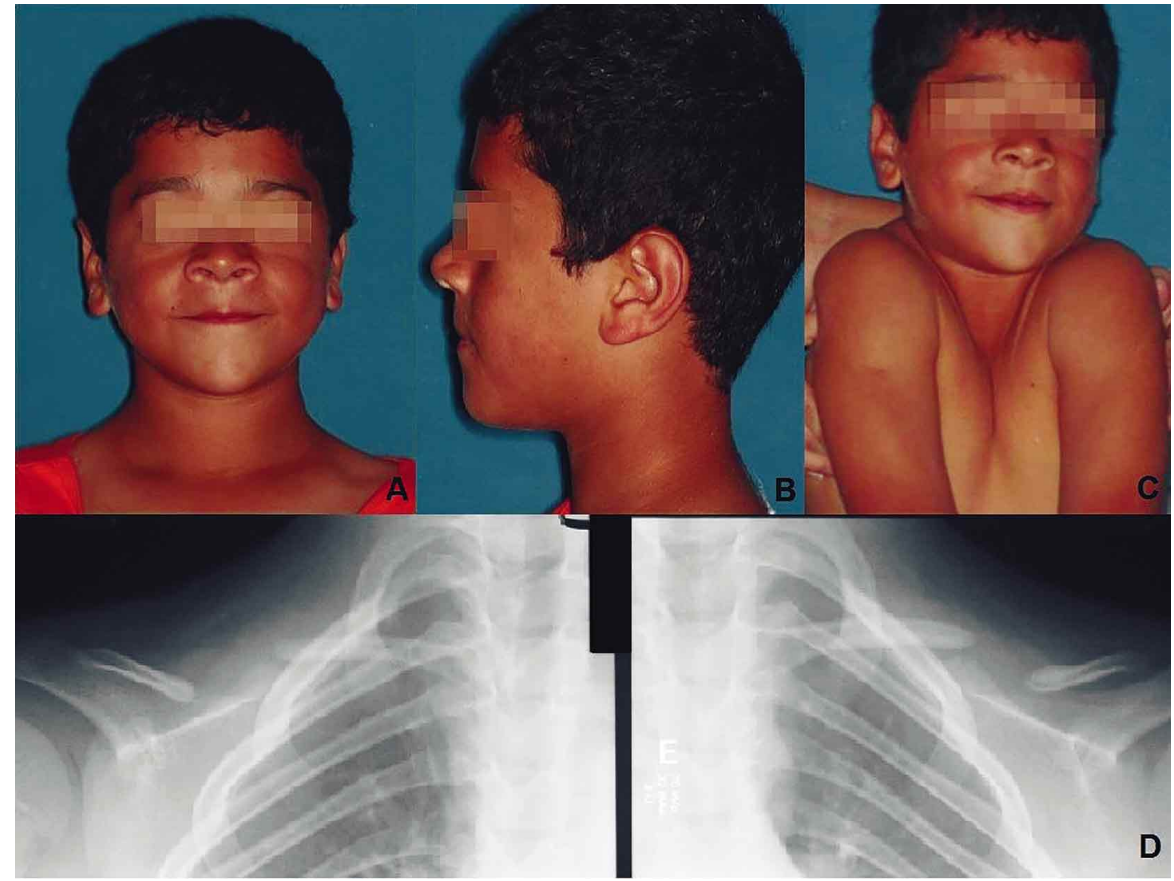

Fig. 1. (A) Front view observing broad base and depressed dorsum of the nose; (B) Side view observing mild mandibular protrusion and a straight profile compatible with skeletal class III; (C) Front view demonstrating unusual shoulder mobility; (D) X-ray showing agenesis of middle third of right and left clavicles. 


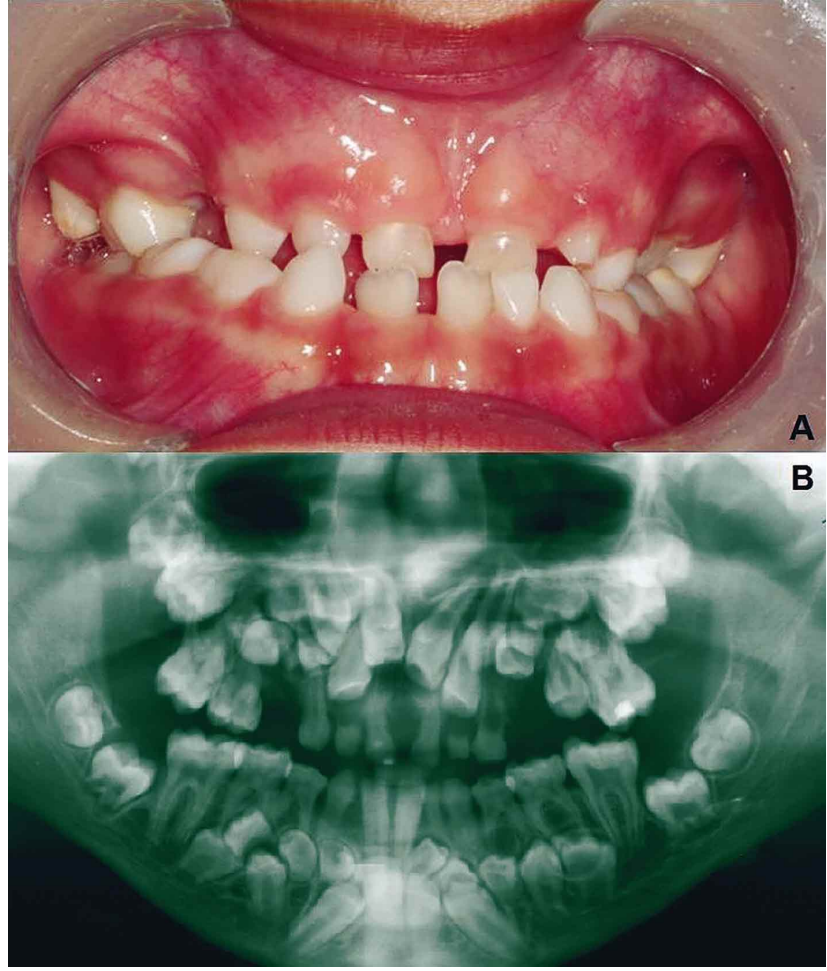

Fig. 2. (A) Intra-oral view showing the retention of primary teeth, anterior and posterior dental crossbite and midline deviation; (B) Initial panoramic radiograph showing impacted permanent teeth, root and crown dilacerations and various supernumerary teeth in anterior region of maxilla and mandible.
Sixty days after surgery, the vestibular arch and traction accessories for the maxillary lateral incisors were removed and a dento-muco-supported Haas appliance was fixed for separation of the palate (Fig. 4A). The expander was modified to the patient, with the embedding of hooks in the acrylic. Palatal separation was begun with the activation of the expander screw once a day for 30 days. After complete disjunction (Fig. $4 \mathrm{~B})$, traction was begun of the permanent maxillary left central incisor and supernumerary tooth corresponding to the permanent maxillary right central incisor, supported by the hooks on the Hass appliance with elastic bands. Reverse traction of the maxilla was also begun with the aid of a Petit headgear and recommendations for use $12 \mathrm{~h}$ a day. Mesh was bonded to the permanent maxillary canines for subsequent traction. This traction would only occur after the extraction of the primary maxillary canines, which were assisting in the retention of the Haas expander.

After two months of traction, the patient complained of gingival bleeding and a metal traction wire was found to be injuring the gingival tissue. A soldered lingual arch was then made with bands on the permanent mandibular right and left first molars and hooks in the anterior region to allow the use of intraoral elastic bands (Fig. 5). This allowed traction of
Fig. 3. (A) Primary maxillary incisors extracted; detachment and visualization of entire anterior structure of maxilla; (B) Extraction of two supernumerary teeth, maxillary right central incisor and maxillary right second premolar; (C) Mesh for traction of permanent and supernumerary teeth; (D) Wires attached to vestibular arch fixed by orthodontic bands on maxillary right and left first molars; (E) Extractions of the 4 primary maxillary incisors, 2 supernumerary teeth located in the anterior region and 2 permanent teeth.

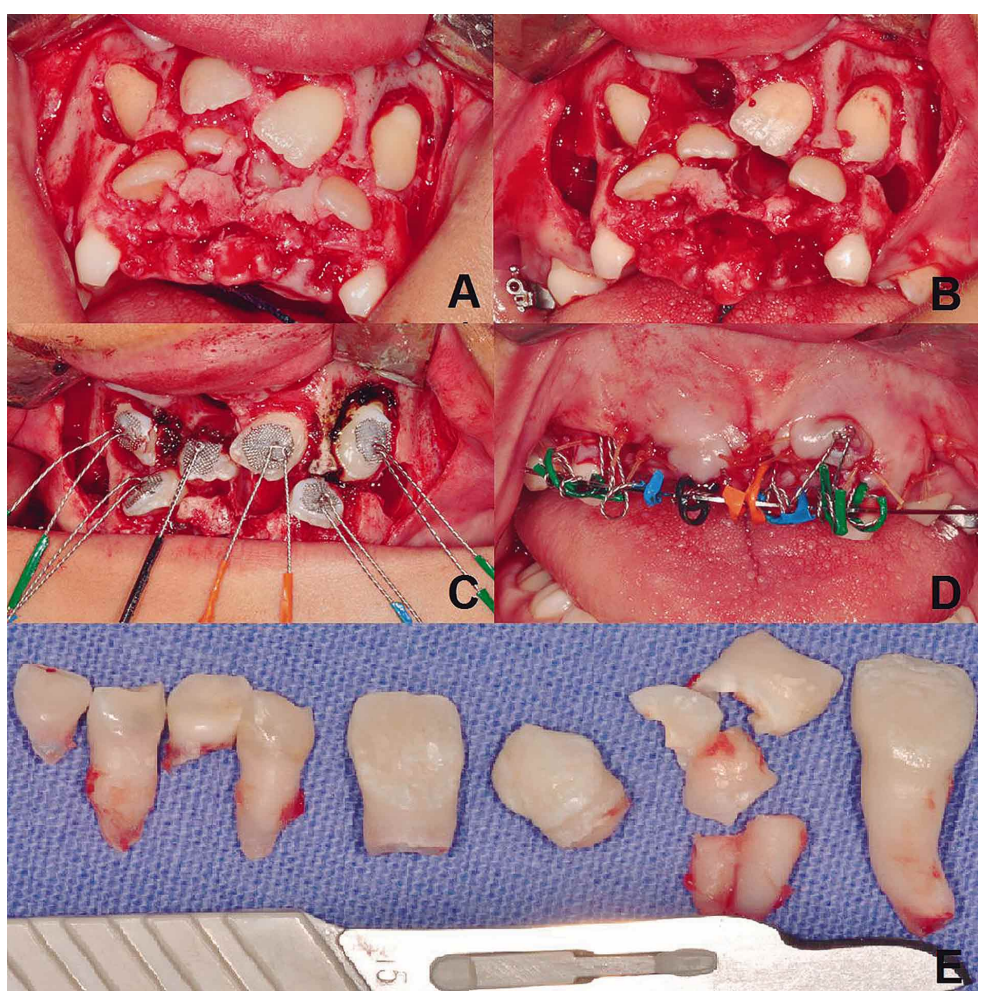




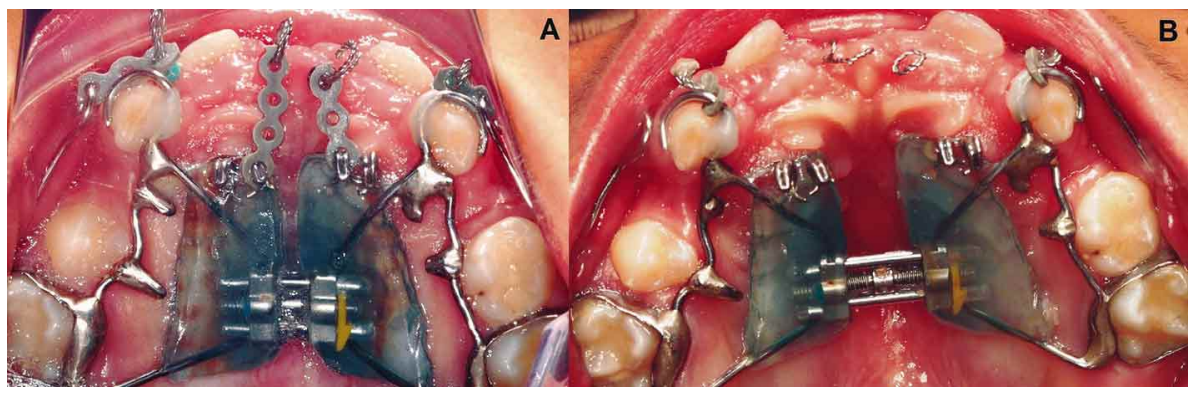

Fig. 4. (A) The dento-muco-supported Haas appliance fixed for separation of the palate;

(B) Palatine disjunction completed.

the maxillary teeth without the metal wires pressing against the gingival tissue. The disadvantage of this method resides in the dependence on patient cooperation regarding the use of the elastic bands, which are removed during eating and should be replaced afterward. After 60 days of use, the patient was not yet fully adapted to the placement of the elastic bands and

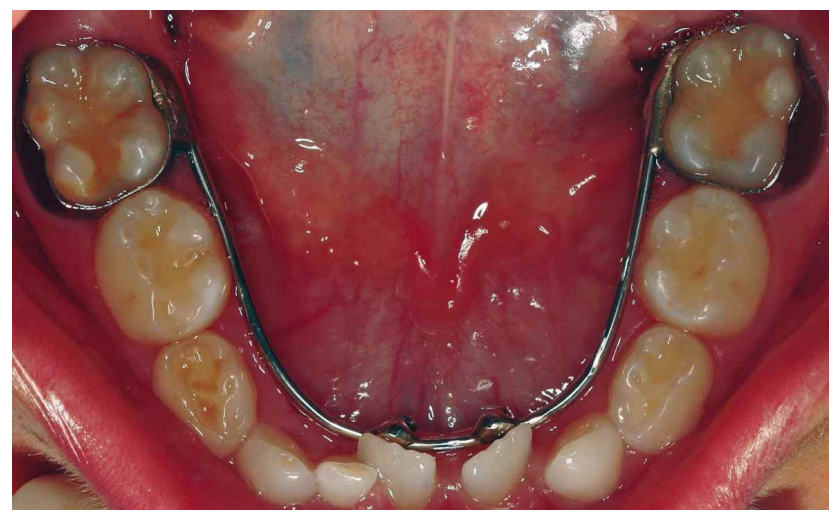

Fig. 5. The soldered lingual arch made with bands on the permanent mandibular right and left first molars and hooks in the anterior region to allow the use of intraoral elastic bands.

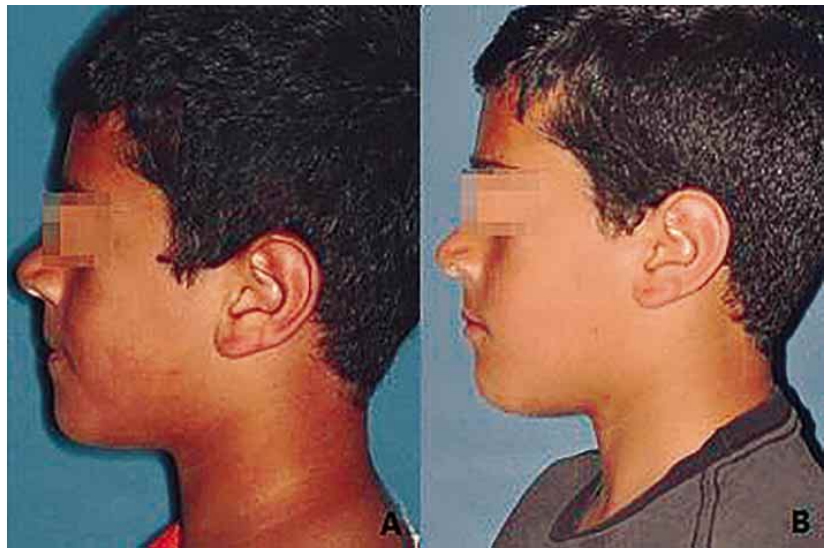

Fig. 6. (A) Patient profile at initial clinical exam and (B) eight months after onset of treatment. relied on his parents to perform this task. Thus, the period of daily use has been reduced substantially, which could lead to a delay in the treatment.

To date, only slight movement has been observed of the teeth submitted to traction, with no signs of eruption. The use of the headgear has been effective and significant improvements in the class III relationship and profile of the patient have been observed (Fig. 6A-B).

\section{DISCUSSION}

The clinical and radiographic exams of the patient revealed pathognomomic characteristics for the diagnosis of CCD (Purandare et al.). There is no treatment for bone abnormalities associated with this condition (Neville et al.). However, treatment options for oral manifestations include the extraction of all teeth followed by the placement of complete dentures (Winter; Jensen \& Kreiborg) or the surgical removal of primary and supernumerary teeth combined with orthodontic traction of the impacted permanent teeth (Winter; Jensen \& Kreiborg; Park et al., 2013). The literature presents four main approaches to the latter option: Toronto-Melbourne, Belfast-Hamburg, Jerusalem, and Bronx methods (Roberts et al., 2013), which differ in the number of surgical interventions provided. Due to the patient's age, the surgical removal of primary and supernumerary teeth combined with orthodontic traction of the impacted permanent teeth was the treatment of choice in the present case, which can prevent the shortening of facial height and mandibular protrusion when performed in the growth phase (Neville et al.). In this case, the approach was closer to the Jerusalem (Becker et al., 1997), with minor adjustments due to specifics of the patient. 
The time of diagnosis is important to the adequate choice of treatment and obtainment of a satisfactory outcome. The chronological and dental ages of the patient exert a strong influence on the type of treatment (Jensen \& Kreiborg). However, there are situations in which it is necessary to perform orthognathic surgery after the complete growth of the patient in order to correct the positioning of the maxilla and mandible and obtain a better jaw relationship (Hall \& Hyland, 1978). This option will yet be analyzed in the present case.

The treatment of choice in the present case was similar to methods described in previous papers and the patients in these reports exhibited positive responses to treatment (Park et al.; Nagarathna et al., 2012; Hemalatha \& Balasubramaniam, 2008). Orthodontic traction is generally initiated soon after the surgical intervention and exposure of the impacted teeth (Nagarathna et al.; Hemalatha \& Balasubramaniam). In the present case, however, the traction technique was modified due to the extensive osteotomies and the need to await the formation of new bone tissue. Therefore, traction was only initiated three months after the surgical intervention. Cases such as this require treatment plans with a high degree of complexity, often resulting in a less conventional protocol. Adaptations should be performed considering the needs of each patient, while always respecting the technical principles. Moreover, the complexity of CCD requires a multidisciplinary approach (Roberts et al., 2013). The present case involved pediatric dentists, orthodontists, oral-maxillofacial surgeons and orthopedists.

This case has been followed up for one year and signs of success have been observed in the first phase of treatment, such as small movements of the impacted teeth and the positive response to the use of the Petit headgear, with significant improvements in the class III relationship and profile of the patient.

However, the treatment is long. Thus, clinical follow up as well as the awareness and motivation of the family are key factors. The treatment for the mandible will be carried out only after further evolution of the maxillary treatment.

MORIKAVA, F. S.; SCARIOT, R.; MOROSINI, I. A. C.; SEBASTIANI, A.; COSTA, D. J.; FRAIZ, F. C. \& FERREIRA, F. M. Displasia cleidocraneal: Diagnóstico, planificación quirúrgica y ortodóncica e intervenciones en un paciente pediátrico. Int. J. Odontostomat., 10(2):325-331, 2016.

RESUMEN: La displasia cleidocraneal (CCD) es un trastorno óseo, autosómico dominante, causado por un defecto en el gen CBFA1 y se caracteriza por anomalías esqueléticas, craneofaciales y bucodentales. En este trabajo se describen los principales aspectos de un caso de CCD, desde el diagnóstico y la planificación para la primera etapa de las intervenciones. Un paciente varón de 11 años de edad, concurrió a la Clínica de Odontología Pediátrica de la Universidad Federal de Paraná (Brasil) con un problema de retención prolongada de casi todos sus dientes de leche. Se describen los exámenes clínicos y de imagen dirigidos al diagnóstico de la CCD y el plan de tratamiento. La primera etapa consistió en la extracción de cuatro dientes primarios, dos dientes permanentes y dos dientes supernumerarios del maxilar, seguido de separación del paladar, tracción de los dientes afectados y tracción inversa del maxilar. El paciente permanece en tratamiento. El seguimiento clínico, así como la concientización y motivación de la familia son factores importantes en este tipo de casos.

PALABRAS CLAVE: displasia cleidocraneal, enfermedades de los huesos, diente, supernumerario.

\section{REFERENCES}

Becker, A.; Lustmann, J. \& Shteyer, A. Cleidocranial dysplasia: Part 1--General principles of the orthodontic and surgical treatment modality. Am. J. Orthod. Dentofacial Orthop., 111(1):28-33, 1997.

Björn, H. \& Grahnén, H. Cleido-cranial dysostosis. Odontol. Revy, 17(2):167-75, 1966.

Cooper, S. C.; Flaitz, C. M.; Johnston, D. A.; Lee, B. \& Hecht, J. T. A natural history of cleidocranial dysplasia. Am. J. Med. Genet., 104(1):1-6, 2001.
Hall, R. K. \& Hyland, A. L. Combined surgical and orthodontic management of the oral abnormalities in children with cleidocranial dysplasia. Int. J. Oral Surg., 7(4):267-73, 1978.

Hemalatha, R. \& Balasubramaniam, M. R. Cleidocranial dysplasia: a case report. J. Indian Soc. Pedod. Prev. Dent., 26(1):40-3, 2008.

Jarvis, J. L. \& Keats, T. E. Cleidocranial dysostosis. A review of 40 new cases. Am. J. Roentgenol. Radium Ther. Nucl. Med., 121(1):5-16, 1974. 
Jensen, B. L. \& Kreiborg, S. Dental treatment strategies in cleidocranial dysplasia. Br. Dent. J., 172(6):243-7, 1992.

Kalliala, E. \& Taskinen, P. J. Cleidocranial dysostosis. Report of six typical cases and one atypical case. Oral Surg. Oral Med. Oral Pathol., 15:808-22, 1962.

Lo Muzio, L.; Tetè, S.; Mastrangelo, F.; Cazzolla, A. P.; Lacaita, M. G.; Margaglione, M. \& Campisi, G. A novel mutation of gene CBFA1/RUNX2 in cleidocranial dysplasia. Ann. Clin. Lab. Sci., 37(2):115-20, 2007.

Markovic, M. D. At the crossroads of oral facial genetics. Eur. J. Orthod., 14(6):469-81, 1992.

Mohan, R. P.; Suma, G. N.; Vashishth, S. \& Goel, S. Cleidocranial dysplasia: clinico-radiological illustration of a rare case. J. Oral Sci., 52(1):161-6, 2010.

Mundlos, S. Cleidocranial dysplasia: clinical and molecular genetics. J. Med. Genet., 36(3):177-82, 1999.

Nagarathna, C. N.; Shakuntala, B. S.; Mathew, S.; Krishnamurthy, N. H. \& Yumkham, R. Cleidocranial dysplasia presenting with retained deciduous teeth in a 15-year-old girl: a case report. J. Med. Case Rep., 6:25, 2012.

Neville, B. W.; Damm, D. D.; Allen, C. M. \& Bouquot, J. E. Oral and Maxillofacial Pathology. $3^{\text {th }}$ ed. St. Louis, Saunders/Elsevier, 2009.

Park, T. K.; Vargervik, K. \& Oberoi, S. Orthodontic and surgical management of cleidocranial dysplasia. Korean $\mathrm{J}$. Orthod., 43(5):248-60, 2013.

Purandare, S. M.; Mendoza-Londono, R.; Yatsenko, S. A.; Napierala, D.; Scott, D. A.; Sibai, T.; Casas, K.; Wilson, P.; Lee, J.; Muneer, R.; Leonard, J. C.; Ramji, F. G.; Lachman, R.; Li, S.; Stankiewicz, P.; Lee, B. \& Mulvihill, J. J. De novo three-way chromosome translocation $46, \mathrm{XY}, \mathrm{t}(4 ; 6 ; 21)(\mathrm{p} 16 ; \mathrm{p} 21.1 ; \mathrm{q} 21)$ in a male with cleidocranial dysplasia. Am. J. Med. Genet. A, 146A(4):453-8, 2008.

Regezi, J. A., Sciubba, J. J. \& Jordan, R. C. K. Oral Pathology: Clinical Pathologic Correlations. $6^{\text {th }}$ ed. St. Louis, Saunders/Elsevier, 2012.

Rimoin, D. L. International Nomenclature of Constitutional Diseases of Bone: revision-May, 1977. Birth Defects Orig. Artic. Ser., 14(6B):39-45, 1978.

Roberts, T.; Stephen, L. \& Beighton, P. Cleidocranial dysplasia: a review of the dental, historical, and practical implications with an overview of the South African experience. Oral Surg. Oral Med. Oral Pathol. Oral Radiol., 115(1):46-55, 2013.
Winter, G. R. Dental conditions in cleidocranial dysostosis. Am. J. Orthod. Oral Surg., 29(2):61-89, 1943.

Yoshida, T.; Kanegane, H.; Osato, M.; Yanagida, M.; Miyawaki, T.; Ito, Y; \& Shigesada, K. Functional analysis of RUNX2 mutations in Japanese patients with cleidocranial dysplasia demonstrates novel genotypephenotype correlations. Am. J. Hum. Genet., 71(4):72438, 2002.

Correspondence to:

Fernanda Morais Ferreira

Department of Stomatology

Federal University of Parana

Curitiba, Brazil. Av. Pref. Lothário Meissner, 632

Curitiba-PR 80210-170

BRAZIL

Email: femoraisfe@gmail.com

Received: 11-10-2014

Accepted: 13-01-2016 